\title{
Early Education Innovation at Elementary School in Pandemic Covid- 19 Era
}

\author{
Salmon Charles P.T Siahaana), Florence Pribadi, Natalia Yuwono, Rahajoe Imam \\ Santosa, Bella Meylani Lifindra, Azyvati Karensa Putera, and Cassey Clarissa \\ Gondo
}

\author{
Fakultas Kedokteran Universitas Ciputra, Surabaya, Indonesia \\ a)Corresponding author: charles.siahaan@ciputra.ac.id
}

\begin{abstract}
The Grand Convalescene event was divided into handbook socialization and webinars with "Kesiapan Pendidikan Era New Normal" as the theme. The purpose of this event is to provide education, especially in the medical field, about preventing the spread of the COVID-19 and to prepare teachers and their staff to face the New Normal era. The method used in the community service activities was an online webinars, in the form of socialization and evaluation using questionnaire. The results of the analysis carried out using the questionnaire showed that by holding this event, participants became more aware of all forms of information that could help them understand COVID-19 prevention and preparation for the New Normal era. The conclusions of this activity were socialization activities provide benefits for the community and teachers in understanding the conditions in the New Normal era, then this activity helps the community and teachers to prepare themselves for facing the New Normal era, and finally helps the community and teachers in understand the prevention of COVID-19.
\end{abstract}

Keywords : Webinars, Socialization, New Normal, COVID-19, Teacher

\section{INTRODUCTION}

Coronavirus Disease-2019 or COVID-19 is a disease caused by the Severe Acute Respiratory Syndrome Coronavirus 2 (SARS-CoV-2). Symptoms of COVID-19 such as common respiratory diseases include runny nose, sore throat, cough, and fever. Symptoms can vary, ranging from mild to severe illness and continue until death (Kemenkes RI, 2020). Transmission of the virus can be through direct contact (droplets and human-to-human transmission) and indirect contact (contaminated objects and airborne transmission). COVID-19 has spread rapidly throughout the world since it was first identified in Wuhan, China, in December at 2019 (Lotfi et al., 2020; Ouassou et al., 2020).

During 2020, the COVID-19 pandemic has had many impacts on various aspects of life, one of which is education. The PSBB protocol applied makes face-to-face learning activities impossible to carry out. The government urges that learning and teaching activities are carried out using an online system. This aims to break the chain of spread of COVID-19 by reducing crowds or various forms of association. (Siahaan et al., 2020; Syah, 2020; Waluyati, 2020).

The decision to reopen schools must be accompanied by effective measures to minimize the risk of transmission. Children and adolescents can become asymptomatic reservoirs of SARSCoV-2. Therefore, children play a role in the transmission of the virus in the community, especially considering the large number of contacts that children have in environments such as day care center and schools. The important thing to do is to review how schools can remain open without becoming a center of transmission of SARS-CoV-2 (Fontanet et al., 2021; Hyde, 2020).

Implementation of face-to-face learning process requires a lot of preparation. The school needs to prepare sanitation and hygiene facilities and maintain classroom conditions that are in accordance with the health protocol criteria. Then, health behaviors must also be implemented by teaching staff, employees and students such as washing hands, wearing masks, maintaining distance and applying cough/sneeze etiquette. The purpose of such behavior is to reduce the risk of contamination and spread of infection (Hyde, 2020). 
Teachers have an important role in education in the 'New Normal' era. Teacher must be able to do interactive learning. In addition, teachers must be able to apply PHBS (Healthy and Clean Lifestyle) and health procedures in schools. Teachers need to prepare themselves before entering face-to-face learning activities in the new school year. Based on Bintari et al, to preventing the spread of covid-19 especially in the school environment, we need cross sector cooperation from government, society, busines world and academia (Ratih Kusumaningrum et al., n.d.; Waluyati, 2020).

Therefore, the Ciputra University community service team carried out The Grand Convalescence activity which consisted of handbook socialization to teachers at Sambikerep II State Elementary School and Wiyung I/453 State Elementary School and webinars aimed for the general public. The theme of the handbook socialization was "Healthy Schools in a Pandemic Period" and the theme of the online webinar was "Education Readiness for the New Normal Era". The purpose of these two activities is to prepare teachers for face-to-face learning and health procedures applied during the 'New normal' era and to understand some information about reproductive health. (Sheikh et al., 2020; Suwardi et al., 2020).

\section{METHOD}

This Community service contain two activities, fist is the socialization of the handbook content was carried out to teachers from Sambikerep II State Elementary School and Wiyung I/453 State Elementary School. The handbook distributed which contains a clean and healthy lifestyle in an effort to prevent COVID-19. The socialization was held online with lecturers from the Faculty of Medicine, Ciputra University to increase the understanding of elementary school teachers regarding the contents of the handbook and be able to apply its contents during learning activities.

The Second activity is the webinar with theme "Education Readiness for the New Normal Era". With this theme, it is hoped that the community can add insight and increase readiness in entering the New Normal era, especially teachers. This webinar will be presented by several source who are experts in their fields so that participants can interact by asking questions during the question and answer session. The materials presented in the webinar include reproductive health, educational readiness for the New Normal period, and the readiness of elementary school teachers to enter the new normal era.

\section{RESULT}

The result of this activity is that teachers from Sambikerep II State Elementary School and Wiyung I/453 State Elementary School can understand the contents of the handbooks that have been given and can apply its contents in learning activities in elementary schools. This activity is expected to prepare teachers before starting face-to-face learning in the New Normal era. The handbook socialization activity was conducted online to 53 participants, namely 28 teachers from Sambikerep II State Elementary School and 23 teachers from Wiyung I/453 State Elementary School.

The result of the webinar activity "Education Readiness for the New Normal Era" is that the community and Ciputra University students can understand the readiness to enter the New Normal era of education as well as materials related to the COVID-19 pandemic. Webinar activities are packaged in the form of material presentations by three source who are experts in their respective fields. In addition, seminar participants were also given the opportunity to interact with sources through a question and answer session after the presentation of the material was completed. The number of participants for the Webinar activity is 79 people with a total of 33 students from Ciputra University and 46 people from the general public.

\section{DISCUSSION}

From the socialization of the handbook, we collecting the questionnaire 2 times, the Initial Questionnaire which was carried out before the material was given and the Final Questionnaire was carried out after the material had been given. The purpose of this questionnaire is to assess 
the level of understanding of participants before and after the Handbook Socialization event. For values 0-30 categorized for 'less' understanding, values of 40-60 categorized to 'moderate' understanding, and scores of 70-100 including the category of 'high' understanding. The results of the questionnaire showed an increase in participants' understanding after the material was given.

From Table 1, for the Initial Questionnaire, the average value (Mean) is 49.06 while the Final Questionnaire has an average value of 62.81. The average value of the Final Questionnaire is greater than the average of the Preliminary Questionnaire (62.81>49.09) so descriptively, there is a difference in the average score of the questionnaire after the presentation of the material by the speaker. We did statistical tests on the outcomes after the event was held, we got $p$ value $=0.0014$ $(r=0.5006)$, this shows that there is a change in the knowledge of the training participants after the webinar event took place with an strength of 0.5 times greater than before the handbook socialization webinar event.

From the webinar "Education Readiness for the New Normal Era" we collecting Questionnaires at the beginning and end of the event. This questionnaire aims to assess the level of understanding of participants before and after the Webinar event. For values 0-30 categorized to 'less' understanding, values of 40-60 categorized to 'moderate' understanding, and scores of 70-100 categorized to 'good' understanding. The results of the questionnaire showed an increase in participants' understanding after the material was given.

From Table 2, for the Initial Questionnaire, the average value (Mean) is 60.22 while the Final Questionnaire has an average value of 67.17. The average value of the Final Questionnaire is greater than the average of the Preliminary Questionnaire $(60.22>67.17)$ so descriptively, there is a difference in the average score of the questionnaire after the presentation of the material by the speaker. We did a statistical test on the output after the event was held, we got a $p$ value $=0.035$ $(r=0.2103)$, this shows that there is a change in the knowledge of the training participants after the New Normal era education webinar took place.

\section{CONCLUSIONS AND RECOMMENDATIONS}

The conclusions of the online handbook and webinar socialization activities that have been carried out are as follows:

a. School has better understanding of the conditions in the New Normal era

b. Communities and teachers can prepare themselves to face learning in the New Normal era

c. The community and teachers can understand and apply the principles of health protocols in preventing COVID-19 in the school environment.

The event which has been carried out by the Medical's Student Union together with the Faculty of Medicine, Ciputra University Surabaya has been carried out well. Thus, future community service events can provide benefits to the wider community.

\section{ACKNOWLEDGMENTS}

We express our gratitude to God Almighty and the Faculty of Medicine, University of Ciputra, for giving us the opportunity to socialize webinar activities to prepare for learning in the New Normal era. To the Student Union who have worked hard to make this event a success. To elementary school teachers, parents and all webinar participants who are willing to participate and actively participate during the webinar event and to the Abdimas UMTAS Journal who has given the opportunity to give us the opportunity to publish our event.

\section{REFERENCES}

Fontanet, A., Grant, R., Greve-Isdahl, M., \& Sridhar, D. (2021). Covid-19: Keeping schools as safe as possible. In The BMJ (Vol. 372). BMJ Publishing Group. https://doi.org/10.1136/bmj.n524 Hyde, Z. (2020). COVID-19, children and schools: overlooked and at risk. Medical Journal of Australia, 213(10), 444-446.e1. https://doi.org/10.5694/mja2.50823 
Kemenkes RI. (2020). Pedoman Pencegahan dan Pengendalian CoronaVirus Disease (COVID19).

Lotfi, M., Hamblin, M. R., \& Rezaei, N. (2020). COVID-19: Transmission, prevention, and potential therapeutic opportunities. In Clinica Chimica Acta (Vol. 508, pp. 254-266). Elsevier B.V. https://doi.org/10.1016/j.cca.2020.05.044

Ouassou, H., Kharchoufa, L., Bouhrim, M., Daoudi, N. E., Imtara, H., Bencheikh, N., Elbouzidi, A., \& Bnouham, M. (2020). The Pathogenesis of Coronavirus Disease 2019 (COVID-19): Evaluation and Prevention. In Journal of Immunology Research (Vol. 2020). Hindawi Limited. https://doi.org/10.1155/2020/1357983

Ratih Kusumaningrum, B., Dewi Jayanti Jilan Putri, A., Yudha Nagara, A., Hadi Susanto, A., Setyo Rini, I., Ulya, I., Prawestiningtyas, E., Satria Herdiyono, M., Lorensa Krisyanto, A., Nainggolan, M., Keperawatan Fakultas Kedokteran Universitas Brawijaya, J., Program Studi, M. S., \& Jurusan Keperawatan Fakultas Kedokteran Universitas Brawijaya, K. (n.d.). Abdimas Umtas: Jurnal Pengabdian Kepada Masyarakat LPPM-Universitas Muhammadiyah Tasikmalaya Edukasi Perilaku Hidup Bersih Dan Sehat Dalam Pencegahan Penyebaran Covid-19 Di Masyarakat Kota Malang.

Sheikh, A., Sheikh, A., Sheikh, Z., \& Dhami, S. (2020). Reopening schools after the COVID-19 lockdown. In Journal of Global Health (Vol. 10, Issue 1). University of Edinburgh. https://doi.org/10.7189/JOGH.10.010376

Siahaan, M., Akuntansi, P., Ekonomi, F., Bhayangkara, U., Raya, J., Raya Perjuangan, J., Mulya, M., \& Utara, B. (2020). Dampak Pandemi Covid-19 Terhadap Dunia Pendidikan. In Edisi Khusus (Issue 1). http://ejurnal.ubharajaya.ac.id/index.php/JKI

Suwardi, B., Peneliti, J., Muda Pada Puslitjak, A., Penelitian, P., Pendidikan, K., Kebudayaan, D., \& Pendidikan, K. (2020). KESIAPAN SEKOLAH PASCA AKAN DIPERBOLEHKAN PEMBELAJARAN TATAP MUKA.

Syah, R. H. (2020). Dampak Covid-19 pada Pendidikan di Indonesia: Sekolah, Keterampilan, dan Proses Pembelajaran. SALAM: Jurnal Sosial Dan Budaya Syar-i, 7(5). https://doi.org/10.15408/sjsbs.v7i5.15314

Waluyati, I. (2020). Penerapan New Normal Dalam Masa Pandemi Covid 19 di Sekolah Penerapan New NormalDalam Masa Pandemi Covid 19 di Sekolah. EduSociataJurnal Pendidikan Sosiologi, III(2). 


\section{APPENDIX}

Table 1. Handbook socialization statistical analysis results

\begin{tabular}{|c|c|c|c|c|c|c|}
\hline & & Mean & $\mathbf{N}$ & $\begin{array}{c}\text { Std. } \\
\text { Deviation }\end{array}$ & $\begin{array}{c}\text { Std. Error } \\
\text { Mean }\end{array}$ & $p$ value $(r)$ \\
\hline \multirow[t]{2}{*}{$\begin{array}{l}\text { We } \\
\text { bina } \\
\text { r } 1\end{array}$} & $\begin{array}{c}\text { Initial } \\
\text { Questionnair } \\
\mathrm{e}\end{array}$ & 49.06 & 32 & 16.531 & 2.922 & \multirow[t]{2}{*}{$\begin{array}{c}0.0014(r= \\
0.5006)\end{array}$} \\
\hline & $\begin{array}{c}\text { Final } \\
\text { Questionnair } \\
\mathrm{e}\end{array}$ & 62.81 & 32 & 16.310 & 2.883 & \\
\hline
\end{tabular}

Table 2. New Normal Education Webinar Statistical Analysis Results

\begin{tabular}{|c|c|c|c|c|c|c|}
\hline & & Mean & $\mathbf{N}$ & $\begin{array}{c}\text { Std. } \\
\text { Deviation }\end{array}$ & $\begin{array}{l}\text { Std. Error } \\
\text { Mean }\end{array}$ & $p$ value $(r)$ \\
\hline \multirow[t]{2}{*}{$\begin{array}{l}\text { We } \\
\text { bina } \\
\text { r } 2\end{array}$} & $\begin{array}{c}\text { Initial } \\
\text { Questionnair } \\
\mathrm{e}\end{array}$ & 60.22 & 46 & 15.77 & 2.377 & \multirow[t]{2}{*}{$\begin{array}{c}0.035(r= \\
0.2103)\end{array}$} \\
\hline & $\begin{array}{c}\text { Final } \\
\text { Questionnair } \\
\mathrm{e} \\
\end{array}$ & 67.17 & 46 & 15.01 & 2.21 & \\
\hline
\end{tabular}

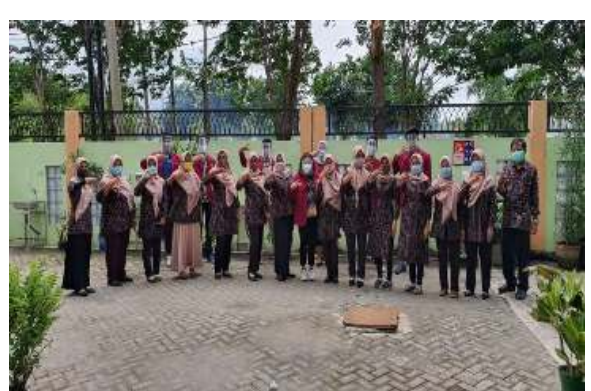

Figure 1. The Grand Convalenscene Committee at Sambikerep II State Elementary School

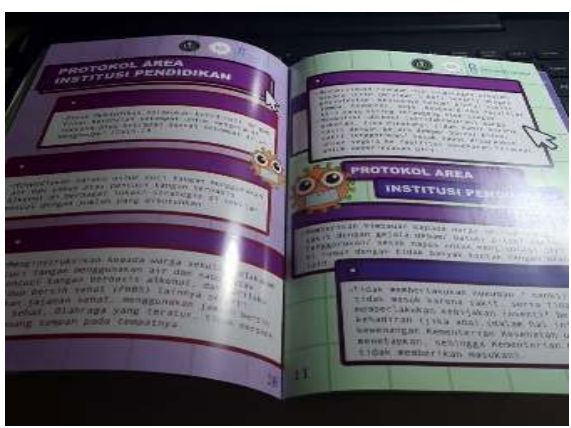

Figure 3. Picture of the Handbook

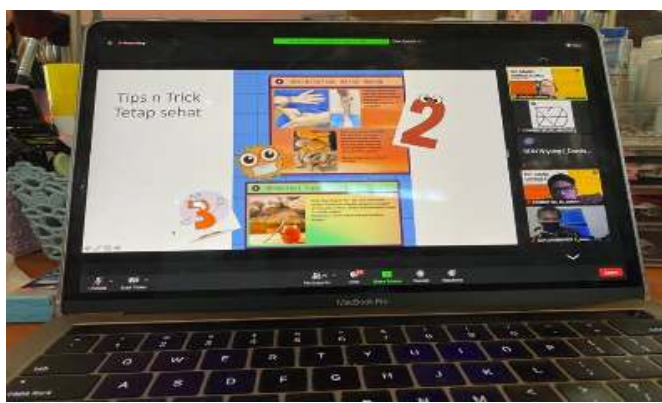

Figure 2. Handbook Socialization Event Documentation

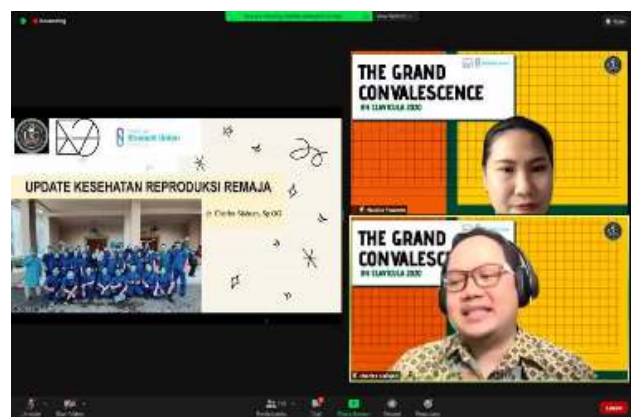

Figure 4. Webinar Event "Education Readiness for the New Normal Era" 